\title{
Edukasi Pencegahan Corona Virus Disease (Covid19) dalam Menghadapi New Normal melalui Whatsapp Group di Desa Pematang Lumut Kecamatan Betara
}

\author{
Faridah $^{1}$, Iin Indrawati ${ }^{2}$ \\ ${ }^{1}$ Program Studi DIII Physiotherapy, STIKes Baiturrahim Jambi \\ ${ }^{2}$ Program Studi DIII Keperawatan, STIKes Baiturrahim Jambi \\ Email: taherfaridah821@gmail.com
}

Submitted : 29/04/2021

Accepted: 08/01/2022

Published: 28/01/2022

\begin{abstract}
The rise of the spread of covid-19 in the world, including Indonesia, especially in Pematang Lumut Village, Tangung Jabung Barat Regency, Jambi Province, worries all parties. Corona virus is a pandemic disease in 2019, where one of the handling and prevention can be done by complying with health protocols. Community service activities were carried out in November-December 2020 with a discussion method and conveying material and pictorial posters related to the corana virus sent via Whatsapp Group. In this pictorial poster there are 4 things, namely (1) Education about Covid-19, (2) Good and Correct Hand Washing Methods, (3) Social Distancing, (4) How to Use Masks. This community service activity begins with a pre-test and ends with a post-test online survey regarding the level of compliance with health protocols during the new normal. This Community Service (PKM) aims to be used as a source of knowledge for the people of Pematang Lumut Village, Betara District, Tanjung Jabung Barat Regency, and can help pay more attention to and comply with health protocols in undergoing New Normal. The results of this activity which were evaluated both through Google Form and the question and answer via Whatsapp Group, were that the average community was satisfied and experienced an increase in understanding of COVID-19 prevention by complying with health protocols.
\end{abstract}

Keywords: education, covid-19 prevention, new norma

\begin{abstract}
Abstrak
Maraknya penyebaran covid-19 di dunia termasuk Indonesia khususnya di Desa Pematang Lumut Kabupaten Tangung Jabung Barat Privinsi Jambi mengkhawatirkan semua pihak. Corona virus merupakan penyakit pandemi di tahun 2019, dimana salah satu penanganan dan pencegahannya dapat dilakukan dengan mematuhi protokol kesehatan. Kegiatan Pengabdian masyarakat dilaksanakan pada Bulan Novenber-Desember 2020 dengan metode diskusi dan menyampaikan materi serta poster bergambar terkait virus corana yang dikirim via Whatsapp Group. Didalam Poster bergambar ini terdapat 4 hal yaitu (1) Edukasi mengenai Covid-19, (2) Cara Cuci Tangan yang Baik dan Benar,(3) Social Distancing,(4) Cara menggunakan Masker. Kegiatan Pengabdian mas yarakat ini diawali pre-test dan diakhiri post-tes survei online mengenai tingkat mentaati protocol kesehatan selama newnormal. Pengabdian kepada Masyarakat (PKM) ini bertujuan untuk dapat dijadikan sebagai sumber pengetahuan masyarakat Desa Pematang Lumut Kecamatan Betara Kabupaten Tanjung Jabung Barat, serta dapat membantu untuk lebih memperhatikan dan mentaati protokol kesehatan dalam menjalani New Normal.Hasil dari kegiatan ini yang dievaluasi baik melalui Google Form maupun tanya jawab melalui Whatsapp Group tersebut adalah rata-rata masyarakat puas dan mengalami peningkatan pemahaman terhadap pencegahan COVID-19 dengan cara mentaati protokol kesehatan.
\end{abstract}

Kata Kunci : edukasi, pencegahan COVID-19, new normal 


\section{PENDAHULUAN}

Coronavirus merupakan jenis virus yang menyebabkan penyakit mulai dari gejala ringan sampai berat. Jenis coronavirus yang dapat menyebabkan penyakit dengan gejala berat misalnya Middle East Respiratory Syndrome (MERS) dan Severe Acute Respiratory Syndrome (SARS). Coronavirus Disease 2019 atau yang disingkat COVID-19adalah penyakit jenis baru yang belum pernah diidentifikasi sebelumnya pada manusia. penyebab COVID-19 ini dinamakan Sars- CoV-2. Virus corona merupakan zoonosis (ditularkan antara hewan dan manusia). Penelitian menyebutkan bahwa SARS ditransmisikan dari kucing luwak (civet cats) ke manusia dan MERS dari unta ke manusia. Adapun, hewan yang menjadi sumber penularan COVID- 19 ini masih belum diketahui (Kemenkes, 2020)

Gangguan pernapasan akut seperti demam, batuk dan sesak napas merupakan tanda dan gejala umum infeksi COVID-19 Masa inkubasi COVID-19 rata-rata 5-6 hari dan masa inkubasi terpanjang adalah 14 hari. Pada kasus COVID-19 yang berat dapat menyebabkan pneumonia, sindrom pernapasan akut, gagal ginjal, dan bahkan kematian. Tanda-tanda dan gejala klinis yang dilaporkan pada sebagian besar kasus adalah demam, dengan beberapa kasus mengalami kesulitan bernapas, dan hasil rontgen menunjukkan infiltrat pneumonia luas di kedua paru (Kemenkes,2020).

Pada 31 Desember 2019, WHO China Country Office melaporkan kasus pneumonia yang tidak diketahui etiologinya di Kota Wuhan, Provinsi Hubei, Cina. Pada tanggal 7 Januari 2020, Cina mengidentifikasi pneumonia yang tidak diketahui etiologinya tersebut sebagai jenis baru coronavirus (coronavirus disease, COVID-19) dan pada tanggal 30 Januari 2020 WHO telah menetapkan sebagai Kedaruratan Kesehatan Masyarakat Yang Meresahkan Dunia/ Public Health Emergency of International Concern
(KKMMD/PHEIC). Penambahan jumlah kasus COVID-19 berlangsung cukup cepat dan sudah terjadi penyebaran antar negara (Kemenkes, 2020).

Informasi tanggal 25 Maret 2020, dilaporkan total kasus konfirmasi 414.179 dengan 18.440 kematian (CFR 4,4\%) dimana kasus dilaporkan di 192 negara/wilayah. Diantara kasus tersebut, sudah ada beberapa petugas kesehatan yang dilaporkan terinfeksi dan ada tanggal 2 Maret 2020,Indonesia melaporkan kasus konfirmasi COVID-19 sebanyak 2 kasus. Sampai dengan tanggal 25 Maret 2020

Indonesia melaporkan 790 kasus konfirmasi COVID-19 dari 24 Provinsi yaitu: Bali, Banten, DIY, DKI Jakarta, Jambi, Jawa Barat, Jawa Tengah, Jawa Timur, Kalimantan Barat, Kalimantan Timur, Kalimantan Tengah, Kalimantan Selatan, Kep. Riau, Nusa Tenggara Barat, Sumatera Selatan, Sumatera Utara, Sulawesi Utara, Sulawesi Tenggara, Sulawesi Selatan, Lampung, Riau, Maluku Utara, Maluku dan Papua. Wilayah dengan transmisi lokal di Indonesia adalah DKI Jakarta, Banten (Kab. Tangerang, Kota Tangerang), Jawa Barat (Kota Bandung, Kab. Bekasi, Kota Bekasi, Kota Depok, Kab. Bogor, Kab. Bogor, Kab. Karawang), Jawa Timur (kab. Malang, Kab. Magetan dan Kota Surabaya) dan Jawa Tengah (Kota Surakarta) (Kemenkes, 2020).

Penularan COVID-19 dapat menular dari manusia ke manusia melalui percikan batuk/bersin (droplet), tidak melalui udara. Orang yang paling berisiko tertular penyakit ini adalah orang yang kontak erat dengan pasien COVID-19 seperti kelurgra, kerabat termasuk yang merawat pasien COVID-19 dalam hal ini adalah petugas kesehatan Upaya untuk mencegah penyebaran infeksi adalah melalui cuci tangan secara teratur menggunakan sabun dan air bersih, menerapkan etika batuk dan bersin, menghindari kontak secara langsung dengan ternak dan hewan liar serta menghindari 
kontak dekat dengan siapapun yang menunjukkan gejala penyakit pernapasan seperti batuk dan bersin. Selain itu, menerapkan Pencegahan dan Pengendalian Infeksi (PPI) saat berada di fasilitas kesehatan terutama unit gawat darurat (Kemenkes, 2020).

Provinsi Jambi terdiri dari 11 Kabupaten/kota itu di antaranya :Kota Jambi, Kabupaten Tanjab Barat, Kabupaten Batang Hari dan Kabupaten Muaro Jambi. Empat wilayah ini tercatat paling banyak terpapar virus corona.Tiga hari beruntun kasus positif COVID-19 di Provinsi Jambi terus bertambah . Per 20 September 2020 positif COVID-19 naik lagi 14 kasus dengan angka yang sama di hari sebelumnya. Penambahan ini secara akumulasi terpapar COVID-19 di Provinsi Jambi menjadi 386 kasus. Menurut Juru Bicara Gugus Tugas Penanganan COVID 19 Provinsi Jambi, penambahan 14 kasus tersebut disumbang dari satu kabupaten yaitu Kabupaten Tanjung Jabung Barat, sehingga total positif COVID-19 Provinsi Jambi menjadi 386 orang.

Masyarakat Tanjung Jabung Barat digemparkan dengan wabah COVID-19 menyerang pekerja SKK Migas Petro China Jabung di desa Pematang Lumut Kecamatan Betara Kabupaten Tanjung Jabung Barat yaitu sebanyak 15 0rang ( Jambi. Com).

Upaya untu pencegan penyebaran COVID-19 yaitu dengan melaksanakan $3 \mathrm{M}$ (Mencucu tangan, Menjaga Jarak, Menggunakan masker). Untuk itu diperlukan Sosialisasi dan Edukasi Pencegahan COVID-19 dalam menghadapai New Normal yang merupakan kunci utama keberhasilan dalam penanganan pandemic COVID-19.

Tujuan kegiatan pengabdian masyarakat ini adalah agarmasyarakat memahami dan mentaati protocol kesehatan saat menghadapi New Normal. Metode yang digunakan adalah share poster bergambar via Whatsapp Group. Poster ini berisi tentang protokol kesehatan saat New Normal, seperti Social Distancing; Cuci Tangan yang Baik dan Benar; serta cara menggunakan Masker yang benar. Kegiatan ini dilaksanakan pada warga desa pematang Lumut Kecamatan Betara Kabupaten Tanjung Jabung Barat.

Kegiatan melibatkan tokoh masyarakat dan warga yang dapat mewakili sehingga diharapkan dapat memberikan informasi kembali kepada keluarga dan masyarakat disekitarnya. Sosialisasi dan edukasi pencegahan Covid-19 melalui poster begambar, menjelaskan materi yang berkaitan dengan COVID_19 via Whatssapp Group ini, kemudian masyarakat memberikan respon dan diskusi Hasil yang diharapkan pada pelaksanakan pengabdian masyarakat ini adalah agar masyarakat dapat memahami danmentaati protoko lkesehatan untuk pencegahan COVID-19 dalam menghadapi New Normal. Kegiatan Pengabdian masyarakat ini diawali dengan survei online untuk mengetahui bagaimana tingkat mentaatiprotokolkesehatan masyarakat Desa Pematang Lumut selamaNewNormal sebelum dan sesudah sosialisasi pengabdian masyarakat dilakukan .

\section{TARGET DAN LUARAN}

Taget luaran Pengabdian masyarakat ini adalah dengan melakukan sosialisasi pencegahan penyebaran COVID-19 melalui poster bergambar terkait pencegahan COVID-19 yang di share via Whatsapp Group, dengan harapan dapat dijadikan sebagai sumber pengetahuan masyarakat Desa Pematang Lumut Kecamatan Betara Kabupaten Tanjung Jabung Barat, serta dapat membantu untuk lebih memperhatikan dan mentaati protokol kesehatan dalam menjalani New Normal. Didalam Poster bergambar ini terdapat 4 hal yaitu (1) Edukasi mengenai COVID-19, (2) Cara Cuci Tangan yang 
BaikdanBenar,(3)Social Distancing,(4) Cara menggunakan Masker.

Selain menghasilkan media leaflet dan poster pengabdian masyarakat ini memiliki luaran publikasi karya tulis ilmiah dan sebagai bahan ajar pada mata kuliah Fisiologi Dasar dan Pathologi Umum, Keperawatan Medikal Bedah

\section{METODE PELAKSANAAN}

Kegiatan Pengabdian masyarakat dilaksanakan pada Bulan NovenberDesember 2020dengan sasaran tokoh Masyarakat dan Warga Pematang Lumut Kecamatan Betara Kabupaten Tanjung Jabung Barat. Kegiatan Pengabdian Kepada Masyarakat (PKM) ini bertujuan untuk meningkatnyaperhatianmasyarakatterhadap protokolkesehatan, dengan cara. memberdayakan Tokoh Masyarakat di Desa Pematang Lumut dalam pelaksanaan sosialisasi dan Edukasi Pencegahan COVID-19.

Kegiatan pengabdian masyarakat ini diharapkan dapat meningkatnya pengetahuan masyarakat Desa Pematang Lumut dalam pencegahan penularan COVID-19 dandapat menerapkan terhadap protokol kesehatan dalam aktivitas sehari-harinya

\section{Pelaksanaan Kegiatan}

Tahap pelaksanaan kegiatan pengabdian kepada masyarakat ini adalah sebagai berikut :

\section{Persiapan}

Tahapan ini merupakan tahapan awal dari pelaksanan Pengabdian Masyarakat , sebelumnya tim pengabdian masyarakat melakukan survey dengan cara berdiskusi denga salah satu tokoh masyarakat Desa Pematang Lumut, setelah itu mengirimkan surat berupa perizinan dari Kepala Desa Pematang Lumut Pada Bulan November 2020. Setelahmendapatizin, selanjutnya Tim Pengabdian Masyarakat melaksanakan sedikit diskusi kembali dengan salah satu tokoh Masyarakat terkait Pengabdian Masyarakatyangakandilaksanakan
.Diskusiberlangsungdenganmenggunakan Handphone / WhatsApp

Tahap berikutmya dalam pesiapan pengabdian masyarakat ini adalah perancangan Materi dan pembuatan poster bergambar Social Distancing, mencuci tangan serta menggunakan Masker(SoDist CuTaBaNarKer) . Sebelum menyampaikan Poster bergambar Tim Pengabdian Masyarakat menyampaikan materi terkait dengan COVID-19yaitu :Penyebab Penyakit , Virus, Covid-19 dan Penyebabnya, Antigen dan Antibodi, Imunitas Tubuh, dan Vaksin Selanjutnya mengirim Poster ini berisi tentang pencegahan COVID-19 dalam menghadapi New Normal yaitu Edukasi tentang COVID-19; Social Distancing; Cara Cuci Tangan yang Baik dan Benar; serta menggunakanMasker (SoDist CuTaBaNarKer).

Adapun Metode kegiatan diskusi selama pengabdian masyarakat pada warga Desa Pematang Lumut dengan mengirim materi dan poster bergambar yang terkait dengan COVID-19

\section{Pelaksanaan}

Pada tahap ini mulai dilakukan sosialisasi dan edukasi terkait pencegahan COVID-19 dengan poster bergambar melalui Whatsapp Group. Tahapan ini dilaksanakan selama 15 hari . poster yang terkait COVID -19 ,dibagikan melalui Whatssapp Group secara bertahap kepadawarga Pematang Lumut Kecamatan Betara Kabupaten Tanjung Jabung Barat kemudian dilakuan diskusi demikian seterusnya dengan materi yang lainnya.

3. Monitoring dan Evaluasi

Monitoring dan evaluasi (Monev) dilakukan secara langsung kepada sasaran. Cakupan Monev dalam kegiatan ini meliputi monev perencanaan dan pelaksanaan dan evaluasi hasil.

Monitoring dan evaluasi dilakukan dengan memberikan angket secara online (melalui google form). .Evaluasi ini bertujuan untuk mengetahui sejauh mana 
respon dan peningkatan pemahaman serta pengetahuan masyarakat terkait Pengabdian Masyarakat yang sudah dilaksanakan. Cakupan monev dalam kegiatan ini meliputi empat aspek, yaitu sebagai berikut .Cakupan Monev dalam kegiatan ini meliputi monev perencanaan dan pelaksanaan dan evaluasi hasil

Hasil evaluasi baik melalui Google Form maupun tanya jawab melalui Whatsapp Group tersebut adalah rata-rata masyarakat puas dan mengalami peningkatan pemahaman terhadap pencegahan COVID-19 dengan cara mentaati protokol kesehatan.

\section{HASIL DAN PEMBAHASAN}

Sosilaisasi menurut Kamus Besar BahasaIndonesia (KBBI) berarti upaya memasyarakatkan sesuatu sehingga menjadi dikenal, difahami, dihayati oleh mayarakat atau pemasyarakatan. Sedangkan pengertian sosialisasi dalam arti luas yaitu suatu proses interaksi dan pembelajaran yang dilakukan seseorang sejak ia lahir hingga akhir hayatnya di dalam suatu budaya masyarakat. Melalui proses sosialisasi maka seseorang dapat memahami dan menjalankan hak dan kewajibannya berdasarkan peranstatusmasingmasingsesuaibudayamasyarakat.

Manfaat sosialiasi dalam masyarakat ada dua tahap, yaitu sebagaiindividu, sosialisasiberfungsisebagaipedomandalamb elajarmengenaldanmenyesuaikan diri dengan lingkungannya, contohnya nilai, norma, dan struktur sosial yang ada pada masyarakatdilingkungantersebut.Sedangkan fungsi sosialisasi bagimasyarakat,yaitu sebagai alat untuk melestarikan, penyebaran, dan mewariskan nilai, norma, serta kepercayaan yang ada pada masyarakat. pembelajaran yang dilakukan individu dalam mengenal lingkungannya, baik lingkungan fisik maupunsosial.

Edukasi atau yang sering juga disebut Pendidikan merupakan segala upaya yang direncanakan untuk mempengaruhi orang lain baik individu, kelompok maupun mayarakat sehingga melakukan apa yang diharapkan oleh pelaku Pendidikan . Dalam kamus besar Bahasa Indonesia (KBBI) Pendidikan berasal dari kata dasar didik (mendidik), yaitu memelihara dan memberi latihan (ajaran pimpinan) mengenai akhlak dan kecerdasan pikiran.

Kegiatan Pengabdian masyarakat ini mengankat tema tema "Sosialisasi dan Edukasi Pencegahan Corona Virus Disese (Covid-19) dalam Menghadapi New Normal melalui Whatsapp Group Warga Desa Pematang Lumut Kecamatan Betara Kabupaten Tanjung Jabung Barat pada BulanDesember 2020 yang sasarannya adalah masyarakat Desa Pematang Lumut Kecamatan Betara Kabupaten Tanjung Jabung Barat. Pengabdian masyarakat ini dilakukan oleh 2 orang orang tim dosen dari program studi D-III Fisioterapi dan D-III Keperawatan.

Sebelum pelaksanaan kegiatantim Pengabdian masyarakat melaksanakan pretest untuk mengetahui tingkat pemahaman mayarakat dalam mentaati Protokol Kesehatan selama New Normal

Adapun Hasil Pre-Tesmeliputi tingkat kepatuhan ,tingkat pemahaman, tingkat mentaati protocol kesehatan tentang COVID-19 sebelum sosialisasi dilaksanakan dapat dilihat pada Gambar. 1, 2 dan 3.

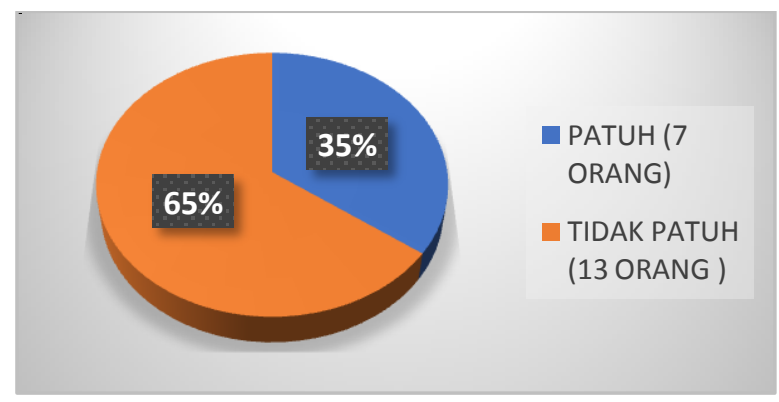

Gambar 1. Diagram Tingkat Kepatuhan Warga dalam melaksanakan Protokol Kesehatan sebelum Sosialisasi 


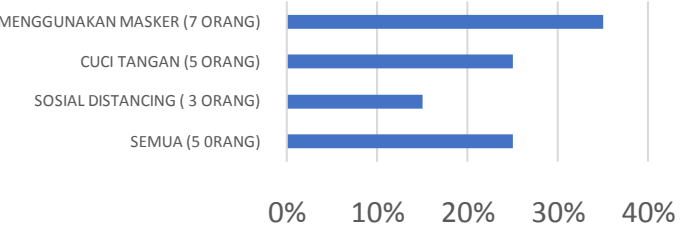

Gambar 2. Diagram Jenis Protokol Kesehatan yang dipatuhi

Sebagian besar warga Desa Pematang lumut hanya mentaati 1 atau 2 dari 3 protokol kesehatan selama pandemi. Terutama social distancing hanya 3 orang yang melaksanakan, dimana masyarakat masih menghadiri acara resepsi pernikahan, pengajian , kumpul-kumpul di warung warung kopi, dll

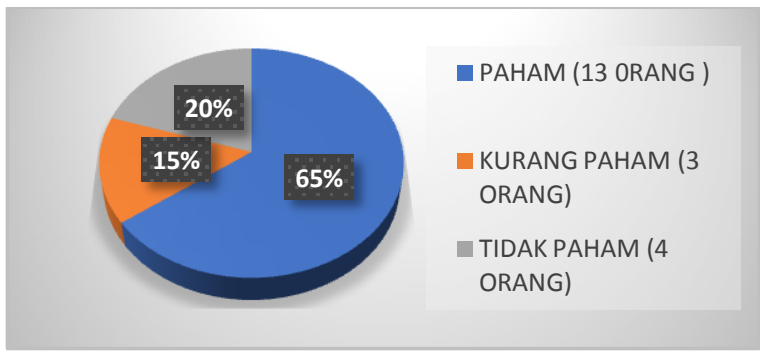

Gambar3.Tingkat Pemahaman Warga Pematang Lumut tentang COVID-19 sebelum edukasi

Hasil survey awal pre-tesyang dilakukan dengan memberikan angket secara online (melalui google form). dapat disimpulkan bahwa Tingkat kepatuhan warga dalam melaksanakan protokol kesehatan warga pematang Lumut yaitu $65 \%$ tidak patuh, namun tingkat pemahamn baik $65 \%$ sedangkan Jenis protokol kesehatan yang dipatuhi warga Desa Pematang Lumut sebelumsosialisasi yaitu : melaksanakan semua protokol kesehatan hanya 5 orang $(25 \%)$, social distancing 3 orang $(15 \%)$, mencuci tangan 5 orang (25\%), menggunakan masker 7 orang $(35 \%)$.

Tingkat pemahaman warga Pemtang
Lumut dapat dikategorikan tinggi yaitu $65 \%$. Pemahaman masyarakat yang tinggi ini dikarenakan sebagian warga yang mengkuti whatsapp group mempunyai tingkat pendidikan tinggi, namun warga yang memiliki tingkat pendidikan rendahbelum tentu memiliki pengetahuan yang rendah terkait covid 19 dikarenakan banyaknya media- media promosi kesehatan yang memberikan pengetahuan bagi masyarakat terkait penyakit covid-19 beserta pencegahan dan pengobatannya.

Rendahnya tingkat kemampuan masyarakat dalam mentaati protokol kesehatan bukan berarti masyarakat tidak mempunyai pengetahuan/ pemahaman terkait covid-19,namun dikarenakan sebelum adanya wabah pandemi Covid 19, warga pematang lumut belumterbiasa menerapkan protokol kesehatansehingga kurangnya pengalaman inilah yang menyebabkan masih belum termotivasi untuk konsisten melaksanakan semua protokol kesehatan sesui yang dianjurkan untuk mencegah penularan covid-19.

Menurut Chotimah, Haryadi, dan Nendyah (2019) Motivasi adalah salah satu faktor yang mendasari seseorang dalam berperilaku menggunakan alat proteksi diri, artinya setiap adanya peningkatan motivasi akan dapat meningkatkan perilaku penggunaan alat proteksi diri dasar. Motivasi juga merupakan suatu faktor yang mempengaruhi kepatuhan seseorang terhadap suatu permasalahan. Motivasi dapat berasal dari diri individu (internal)misalnya harga diri, harapan, tanggung jawab, pendidikan sedangkan yang berasal dari lingkungan luar (eksternal)contohnya hubungan interpersonal, keamanan dan keselamatan kerja, dan pelatihan (Purwanto, 2009).

Motivasi berfungsi untuk menggerakkan dan mendorong timbulnya suatu perbuatan, menentukan arah perbuatan pada tujuan yang hendak dicapai, serta menyeleksi perbuatan dan memilih 
perbuatan yang harusdikerjakandan yang harus disisihkan untuk mencapai tujuan tertentu. (Sardiman, 2016)

Banyak faktor yang mempengaruhi tingginya motivasi masyarakat dalam menjalankan protokol kesehatan di masa pandemi covid 19 misalnya pendidikan, pengetahuan, serta sikap. sedangkan rendahnya motivasi terhadap menjalankan protokol kesehatan di pandemic covid ini disebabkan oleh beberapa faktor misalnya kurang tegas penegakan peraturan, kurangnya role model yang baik, dan lingkungan yang tidak mendukung.(Novi Afrianti, Cut Rahmiati, 2021). Sehingga dapat disimpulkan motivasi yang baik yaitu motivasi yang dapat mendorong masyarakat untuk selalu mematuhi protokol kesehatan covid 19 sehingga diharapkan dapat memutus mata ratai penularan corona virus. Oleh sebab itu, pemerintah harus memiliki strategi tepat untuk dapat menyebarkan informasi terkait covid 19 dan pencegahannya agar

dapatmeningkatkan pengetahuan khususnya bagi masyarakat yang dianggap beresiko dan memiliki pengetahuan yang cenderung rendah tentang penyakit ini.

Setelah memperoleh data tentang penerapam protokol kesehatan masyarakat Desa Pematang Lumut tentang Covd-19 Selanjutnya tim merancang Materi dan pembuatan poster bergambar yang terkait Sosial Distancing, Cuci tangan yang benar, menggunakan masker yang benar (SoDist CuTaBaNarKer). Sebelum menyampaikan Poster-poster bergambar Tim Pengabdian Masyarakat menyampaikan materi terkait Covid-19 dengan bahasa yang mudah dipahami yaitu : Pengenalan tentang virus secara umum, Virus Covid-19 dan Penyebabnya , Antigen dan Antibodi, Imunitas Tubuh, dan Vaksin Setelah warga memahami , maka tim pengabdian masyarakat mengirim Poster terkait Covid19 dalam menghadapi New Normal yaituCara Cuci Tangan yang Baik dan
Benar; Social Distancing; serta menggunakanMaskeryang benar (SoDist CuTaBaNarKer). Penjelasan tentang 7 langkah mencuci tangan yang benar menurut WHO yaitu dapat dilihat pada Gambar 4

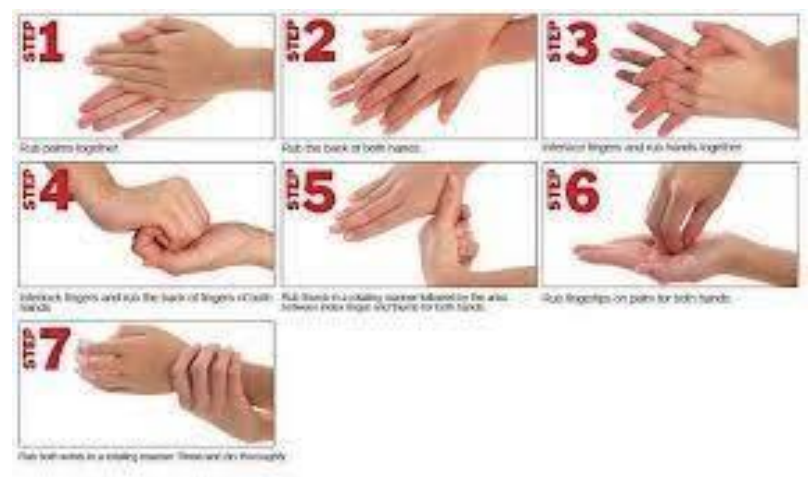

Gambar 4. Tujuh Langkah Mencuci Tangan

Mencuci tangan merupakan salah satu upaya pencegahan COVID-19. Tata cara mencuci tangan harus menggunakan air mengalir dan sabun selama 20-30 detik.Secara umum mencuci tangan dilakukan setelah dari toilet,sebelum makan. Namun, pada masa pandemic ini untu memutus mata rantai cpvid-19 sebaiknya lebih seringjagi untuk mencuci tangan misalnya setelah menyentuh uang, gagng pintu, ketika berada ditempat umum, dan diupayakan untuk tidak menyentuh mulut/hidung , tetapi jika kesulitan menemukan sumber air mengalir, bisa mencuci tangan dengan cairan pembersih yang mengandung alkohol $60 \%$. Mencuci tangan dengan airmengalir dan sabun atau cairan pembersih yang mengandung alkohol dapat membantu menyingkirkan dan membunuh virus yang mungkin terdapat pada tangan dan pastikan mencuci tangan dengan cara yang tepat.

Cara mencuci tangan dapat dilakukan dengan 7 langkah yaitu :

1. Basahi tangan dan tuangkan sabun ditelapak tangan dan gosok sabun yang 
telah dituangkan

2. Tangkupkan kedua telapak tangan dan gosokkan sabun yang telah dituangkan

3. Letakkan telapak tangan kanan diatas punggung tangan kiri dengan jari yang terjalin dan ulangi untuk sebaliknya

4. Letakkan telapak tangan kanan ketelapak tangan kiri dengan jari saling terkait

5. Tangan kanan dan tangan kiri saling menggenggam dan jari bertautan agar sabun mengenai kuku dan pangkal jari.

6. Gosok ibu jari kiri dengan menggunakan tangan kanan dan sebaliknya

7. Gosok jari-jari tangan kanan yang tergenggam ditelapak tangan kiri dan sebaliknya.

Selanjutnya menyampaikan materi tentang manfaat Physical Dischancing. Menurut WHO, pengertian physical distancing adalah pembatasan jarak manusia secara fisik Artinya masyarakat bisa menjaga jarak satu sama lain dengan diam di rumah masing-masing namun jalinan kekeluargaan dan hubungan kekerabatan masih bisa dilakukan di sosial media. Dengan physical distancing ini manusia bukan terisolasi secara sosial dan menjauhi satu sama lain. Masyarakat diminta tetap melakukan interaksi sosial seperti biasa, namun kali ini mungkin dengan cara lain yang tidak memerlukan kehadiran fisik secara langsung, semisal memanfaatkan teknologi informasi dan menggunakan media sosial.

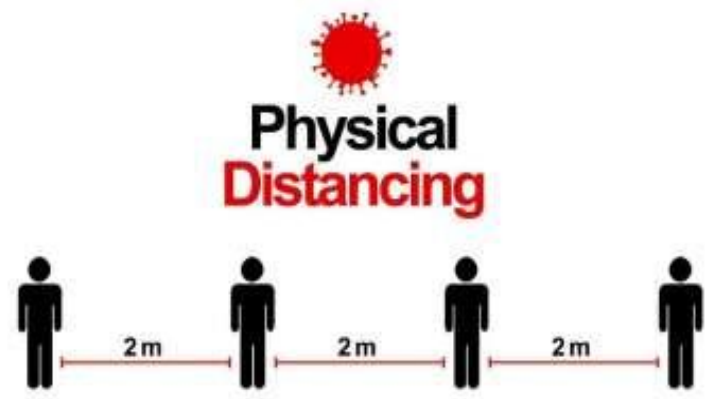

\section{Gambar 5. Penjelasan Tentang Menjaga Jarak}

Menghindari keramaian/kerumunan dan orang lain misalnya ketika ngantri di bank, di pasar apalagi dengan orang yang sedang sakit, termasuk orang yang mengalami gejala batuk atau bersin, paling tidak sejauh 1,5-2 meter. Ketika ada seseorang yang batuk dan bersin, mereka akan mengeluarkan percikan cairan yang mengandung virus dari hidung atau mulutnya. Jika terlalu dekat dengannya, kita bisa menghirup percikan cairan sehingga menyebabkan kita tertular penyakit yang dialami oleh orang tersebut. Hal ini berlaku pula bila seseorang tersebut mengalami COVID-19.

Selanjutnya tim pengabdian masyarakat memberikan leaflet tata cara menggunakan masker .Adapun leaflet yang diberikan kepada warga seperti pada Gambar

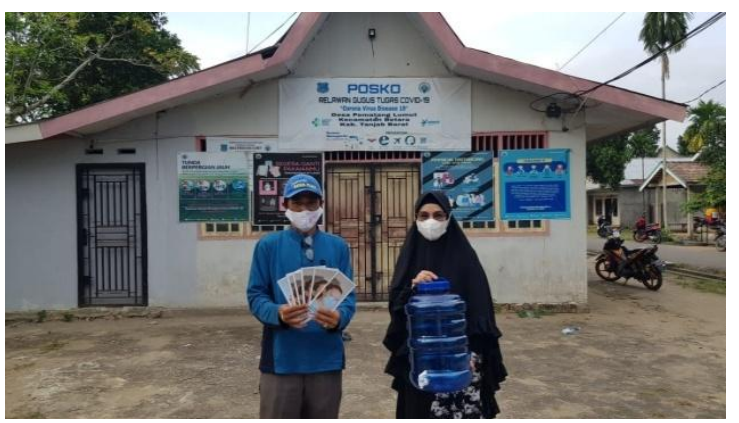

Gambar.6.Penyerahan leaflet cara menggunakan masker yang benar
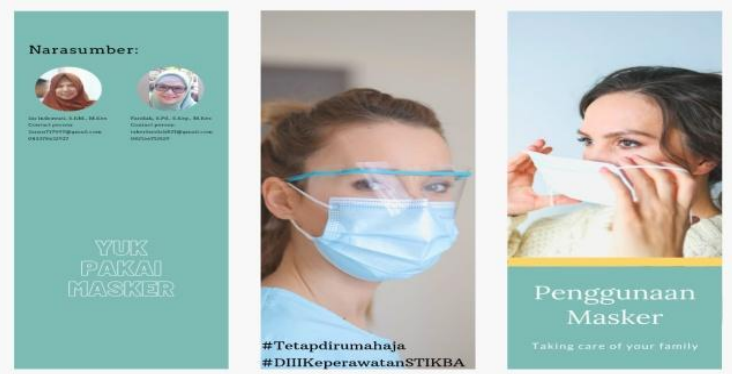

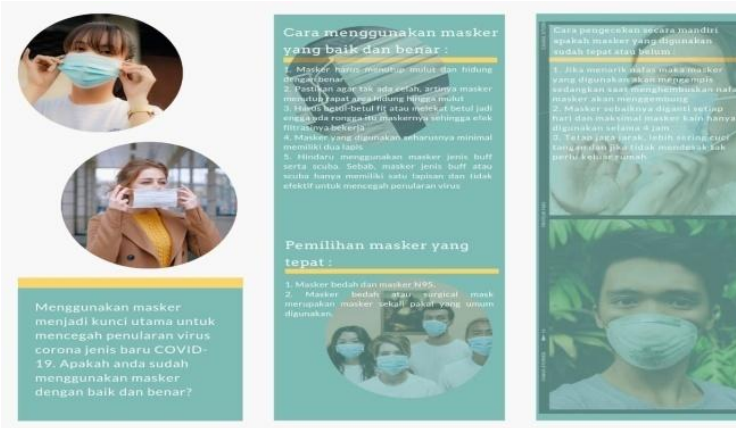

Gambar 7. Contoh leaflet Tentang Menggunakan Masker yang Benar

Cara menggunakan masker yang baik dan benar merupakan salah satu upaya untuk pencegahan COVID-19. Sebelum memakai masker, lakukan hand hygiene yaitu dengan cara mencuci tangan menggunakan sabun atau handrub. Gunakan masker bedah/surgical mask/masker kain dengan sisi yang berwarna di sisi luar ( ada lipatan untuk menyelipkan tissue sebagai pelapis masker ) Pastikan bagian sisi masker yang terdapat kawat berada di sebelah atas di posisi hidung Posisikan masker menutupi seluruh bagian hidung, tarik hingga menutupi dagu. Tekuk kawat di bagian atas masker hingga mengikuti lekuk tulang hidung. Pastikan tidak ada celah antara masker dan wajah. Hindari menyentuh masker, terutama bagian luar, selama pemakaian. Jika tidak sengaja menyentuh masker, cuci tangan menggunakan sabun atau handrub. Lepas dengan menarik tali belakang masker. Hindari menyentuh bagian luar masker. Ganti masker setiap terkontaminasi atau terasa lembab. Segera buang masker ke tempat sampah yang tertutup setelah masker dilepas. Jangan gunakan masker berulang kali dan terkhir kembali lakukan hand hygiene / cuci tangan menggunakan sabun atau handrub setelah melepasmasker.

\begin{tabular}{lrrr}
\multicolumn{1}{c}{ Perlu diingat bahwa tujuan } \\
penggunaan masker adalah untuk \\
mencegah penularan berbagai jenis \\
penyakit yang berasal dari tetesan atau
\end{tabular}

cairan yang dikeluarkan sekaligus melindungi orang lain. Jadi, ketika makan/ berbicara kita selalu menurunkan masker di dagu hingga ke leher lalu menggunakannya kembali ke hidung dan mulut hal ini dapat membuat fungsi masker menjadi tidak optimal lagi untuk melindungi diri dan orang lain dari paparan bakteri dan virus, termasuk virus corona

Setelah pelaksanaan sosialisasi dilaksanakan selanjutnya tim pengabdian masyarakat melakukan Evaluasi kegiatan dengan tujuan untuk mengetahui sejauh mana respon dan peningkatan pemahaman serta kepatuhan masyarakat terkait pengabdian masyarakat sudah dilaksanakan. Diperoleh hasil survey baik melalui Google Form maupun tanya jawab melalui Whatsapp Group tersebut adalah rata-rata masyarakat puas dan mengalami peningkatan pemahaman dan kepatuhan terhadap pencegahan Covid-19 dengan cara mentaati protokol kesehatan.

Jika dibandingkan dengan data sebelum diadakannya kegiatan pengabdian masyarakat ini, terjadi peningkatan yang sangat pesat terkait pemahaman dan kepatuhan masyarakat untuk mentaati protokol kesehatan. Hal ini dapat dilihat berdasarkan diagram dibawah pada Gambar

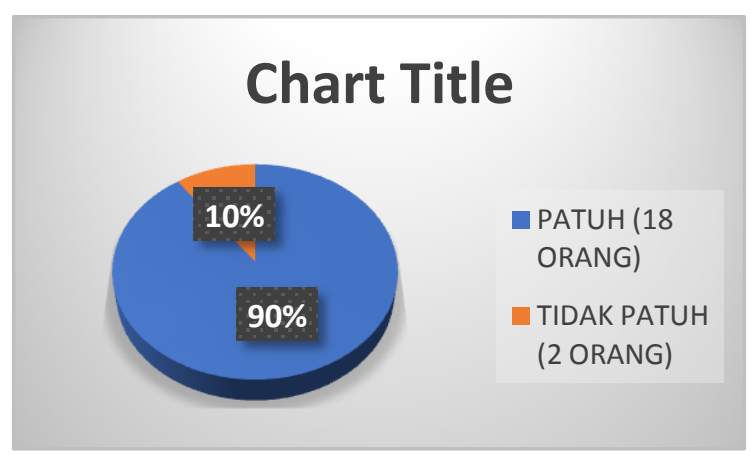

Gambar 8. Diagram Tingkat Kepatuhan Warga dalam melaksanakan Protokol Kesehatan sebelum Sosialisasi 


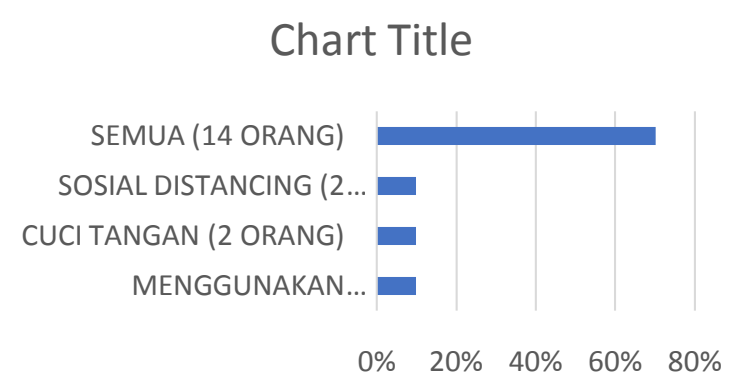

Gambar 9. Diagram Jenis Protokol Kesehatan yang dipatuhi

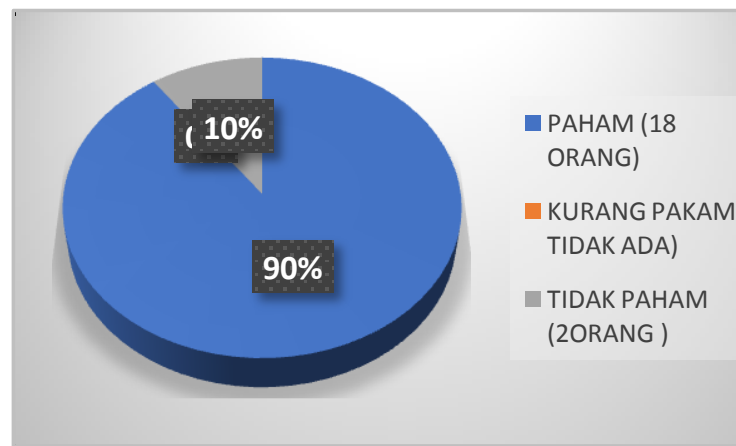

Gambar 10.Tingkat Pemahaman Warga Pematang Lumut tentang COVID-19 sebelumSosialisasi

Hasil survey evaluasi kegiatan posttes yang dilakukan dengan memberikan angket secara online (melalui google form). dapat disimpulkan bahwa Tingkat kepatuhan warga dalam melaksanakan protokol kesehatan warga pematang Lumut yaitu $90 \%$ patuh, tingkat pemahamn baik $90 \%$ dan Jenis protokol kesehatan yang dipatuhi warga Desa Pematang Lumut setelah sosialisasi yaitu : yang melaksanakan semua protokol kesehatan hanya 14 orang $(70 \%)$, namun masih ada yang hanya melaksanakan 1 atau 2 saja protocol kesehatan yaitu: social distancing 2 orang (10\%), mencuci tangan 2 orang (10\%), menggunakan masker 2 orang $(10 \%)$.

Upaya preventif yang disosialisasikan tim pengabdian masyarakat kepada warga Desa pematang Lumut dalam melaksanakan protokol kesehatan untuk memutus mata rantai penularan Covid-19 pada masa $\mathrm{New}$ Normal sudah dipatuhi yaitu warga Desa Pematang Lumut yang ada di sebanyak 20 orang sudah membiasakan diri memakai masker, mencuci tangan pakai sabun (hand sanitanizer), menjaga jarak (social distancing), menjauhi keramaian dan menghindari berpergian ke luar daerah, terutama daerah-daerah yang sudah dinyatakan sebagai zona merah.

Kepatuhan warga dalam melaksanakan protokol kesehatan diatas tidak akan maksimal apabila tidak didukung dengan seluruh masyarakat warga desa Pematang Lumut untuk berpartisipasi. Oleh karena itu diperlukan suatu usaha untuk meningkatkan motivasi kepatuhan masyarakat dalam mendukung berjalannya protocol kesehatan.

Menurut Kozier (2010) kepatuhan merupakan perilaku individu dalam melakukan perubahan gaya hidup, baik iyu dapat dimulai dari tindak mengindahkan setiap aspek anjuran hingga mematuhi rencana. sedangkan Ian \& Marcus (2011) menyatakan bahwa kepatuhan mengacu kepada situasi ketika perilaku seseorangsesuai dengan perbuatan yang dianjurkan atau nasehat yang diusulkan oleh seorang praktisi kesehatan atau informasi yang diperoleh dari suatu sumber informasi lainnya. Smeth dalam Rosa (2018) juga manyatakanbahwa kepatuh(Compliance) merupakan suatubentukperilaku ketaatan seseorang terhadap tujuan yang telahditetapkan.

Menurut Kozier (2010) bahwa faktor yang mempengaruhi terbentuknya kepatuhan seseorang yaitu motivasi, tingkat perubahan gaya yang dibutuhkan, persepsi keparahanmasalah. kesehatan, pengetahuan, dampak dari perubahan, budaya, dan tingkat kepuasan serta kualitas pelayanan kesehatan yang diterima. sedangkan Kamidah (2015) menyebutkan faktor yang mempengaruhi kepatuhan seseoorang berupa pengetahuan, 
motivasi, dan dukungankeluarga.

Kepatuhan dapat ditingkatkan melalui peningkatkan kesadaran masyarakat dengan komunikasi efektif melalui berbagai media dan metode yang sesuai dengan keragaman masyarakat, kampanye yang lebih jelas dan terarah, mempermudah akses kesehatan dengan informasi yang jelas dan terusmenerus sehingga masyarakat cepat melakukan tindakan pemeriksaan, pengobatan dan isolasi mandiri ketika terinfeksi serta kebijakan yang konsisten sehingga tidak membingungkan masyarakat.(Almi 2020)

\section{KESIMPULAN DAN SARAN}

\section{Kesimpulan}

Setelah tim melaksanakan kegiatan pengabdian masyarakat warga Pematang Lumut yang mengikuti whatsapp group mulai mengerti dan memahami tentang pencegahan covid-19

\section{Saran}

Perwakilan whatsapp group hendaknya terus melakukan memberikan informasi dengan komunikasi yang lebih efektif, jelas dan terarah tentang covid-19 sehingga masyarakat memiliki kesamaan pandangan untuk melakukan upaya pencegahan Covid-19 dan apparat kesehatan memberikan akses kesehatan dengan informasi yang jelas dan terusmenerus sehingga masyarakat cepat melakukan tindakan pemeriksaan, pengobatan dan isolasi mandiri ketika terinfeksi.

\section{UCAPAN TERIMAKASIH}

Tim Pengabdian mengucapkan terimakasih kepada STIKes Baiturrahim Jambi atas dukungan moril serta materil sehingga kegiatan ini dapat terlaksana dengan baik.

\section{DAFTAR PUSTAKA}

Almi. (2020). Analisis Penyebab Masyarakat tidak patuh pada protocol Covid-19. diakses pada tanggal 13 Agustus $2020 \quad$ dari https://almi.or.id/2020/06/05/analisispenyebab-masyarakat-tidak-patuhpada-protokol-covid-19/

Ian \& Marcus (2011). Psikologi Kesehatan Panduan Lengkap dan Komprehensif Bagi Studi Psikologi Kesehatan. Cetakan I. Yogyakarta : Palmall

Kementerian Dalam Negeri RI. (2020). Pedoman

Pemerintah Daerah Dalam

Penanganan COVID-19 dan Dampaknya.

KemKesRI (2020). Dashboard Data Kasus COVID-19 di Indonesia. diakses pada tanggal 5Agustus 2020 pada https://www.kemkes.go.id/article/view /20031900002/Dashboard-DataKasus-COVID-19-di-Indonesia.html 